\title{
Effects of Fatty Acids on Carbohydrates and Lipids of Canola Seeds During Germination
}

\author{
M. L. L. Ferrarese, C. R. S. Baleroni and O. Ferrarese-Filho* \\ Department of Biochemistry, University of Maringá, 87020-900 Maringá- PR, Brazil
}

\begin{abstract}
The present work was carried out to investigate the effects of caprylic acid $\left(C_{8}\right)$ and oleic acid $\left(C_{18}\right)$ on carbohydrates and lipids during canola seed germination. The results showed that oleic acid influence carbohydrate concentration but did not influence lipid concentration. Significant results were found with caprylic acid that affected carbohydrates and lipids in cotyledons after three-day germination.
\end{abstract}

Key words: allelochemicals, carbohydrates, lipids, cotyledons, canola

\section{INTRODUCTION}

The phenomenon of allelopathy includes all chemical interactions between plants and microorganisms. Different organic compounds or allelochemicals are released from plants which include fatty acids also. Both, shortchain and long-chain fatty acids can be formed during senescence via acetate pathway or in the soil by microorganisms as a consequence of organic matter degradation (Whitehead and Havely, 1989).

There are few studies that suggested a possible role of fatty acids as allelochemicals. Stevenson (1966) presented a review on lipids in soil and their influence on soil fertility. It is known that long-chain fatty acids show a phytotoxic inhibitory effect on growth of seedlings at very low concentrations.

Haesler (1974) suggested that inhibitory effects of fatty acids on seed germination of Lycopersion esculentum extended to chains with up to 24 carbons. Vanner and Stocker (1977) observed that germination percentage of large seeds such as Cucumis sativus, Picea abies, Sinapis alba and Linum usitatissimum was not influenced by behenic acid $\left(\mathrm{C}_{22}\right)$ at different concentrations. Accentuated reductions in the germination percentage were found in small seeds such as Nicotiana tabacum. In this species, the germination percentage was much lower in seeds treated with $\mathrm{C}_{12}, \mathrm{C}_{18}, \mathrm{C}_{20}, \mathrm{C}_{22}$ and $\mathrm{C}_{24}$ fatty acids. Seeds treated with $\mathrm{C}_{14}$ and $\mathrm{C}_{16}$ fatty acids showed high germination percentage.

Effects of short-chain fatty acids on seed germination were also evident. When chickpea seeds were germinated at $25^{\circ} \mathrm{C}$ in the presence of short-chain saturated fatty acids $\left(\mathrm{C}_{5}-\mathrm{C}_{10}\right)$, the radicle length diminished with the increase of carbon number and fatty acid concentration. After 62 hours germination was inhibited up to $50 \%, 52 \%, 64 \%, 96 \%$ and $98 \%$ by $5 \mathrm{mM}-$ concentration of valeric, caproic, heptanoic, caprylic and capryc acid, respectively (Gallardo et al. 1994). Among the short-chain fatty acids, nonanoic acid was the most effective in preventing the germination of lettuce (Stewart and Berrie, 1979) and wild oats (Metzer and Sebesta, 1982). At $10 \mathrm{mM}$, this fatty acid inhibited the germination of wild oat seeds completely.

Although the effects of fatty acids have been studied in various species, the influences on the seed germination and on mobilization of lipids and carbohydrates in canola cotyledons are not known. In this work, we investigated the effects of caprylic acid $\left(\mathrm{C}_{8}\right)$ and oleic acid $\left(\mathrm{C}_{18}\right)$ on the contents of carbohydrates and

\footnotetext{
Author for correspondence
} 
lipids in the cotyledons of canola during germination.

\section{MATERIALS AND METHODS}

Canola seeds (Brassica napus L. cv Iciola 41, Zeneca Company, Alberta, Canada) were soaked in a solution of $2 \%(\mathrm{v} / \mathrm{v})$ sodium hypochlorite for five minutes and washed thoroughly with deionized water. For each treatment a batch of 100 seeds was spread in plastic boxes $(11 \times 11 \mathrm{~cm})$ with two layers of Whatman filter paper humidified with deionized water with or without fatty acids at concentrations of 1,5 and $10 \mathrm{mM}$. The $\mathrm{pH}$ of the solutions was adjusted to 6.0. All experiments were conducted under aseptic conditions.

The boxes were incubated in a germination chamber (Tecnal TE 400, São Paulo, Brazil) in darkness at $25^{\circ} \mathrm{C}( \pm 0.2)$ and $80 \%$ relative humidity. The time of solution addition, with or without fatty acids, to the dry seeds was taken as the zero time of germination. Germination percentage was evaluated at various intervals of time and it was considered to have taken place when the protrusion of the radicle became evident. To verify the effects of fatty acids on carbohydrates and lipids the cotyledons were detached from the root, after three-days germination.

Lipids of $(1 \mathrm{~g})$ cotyledons were extracted with $20 \mathrm{ml}$ of (2:1) chloroform:methanol, filtered through Whatman paper, and the concentration was determined by sulfo-phosphovanillin (Knight et al. 1972). Soluble carbohydrates of $(1 \mathrm{~g})$ cotyledons were extracted with $10 \mathrm{ml}$ of $80 \%$ aqueous ethanol at $75^{\circ} \mathrm{C}$ for 30 minutes, filtered and determined by phenol-sulfuric acid (Dubois et al. 1965).

Statistical significance of the difference between these parameters was evaluated by means of Student's t-test. The analysis was performed through InStat program (Version 1.12a, GraphPAD Software, 1990). In the figures, each value plotted is the mean of the value determined for three experiments, and vertical bars indicate standard errors of the mean. Symbols * and \# represent pairs of values differing statistically from each other according to the Student's t-test $(\mathrm{p}<0.05)$.

\section{RESULTS AND DISCUSSION}

It is clear from Fig. 1A that canola seed germination at $25^{\circ} \mathrm{C}$ in darkness occurs very rapidly. Eight hours after seed imbibition the protrusion of the radicle became evident and after 24 hours, $90 \%$ or more of the seeds germinated.
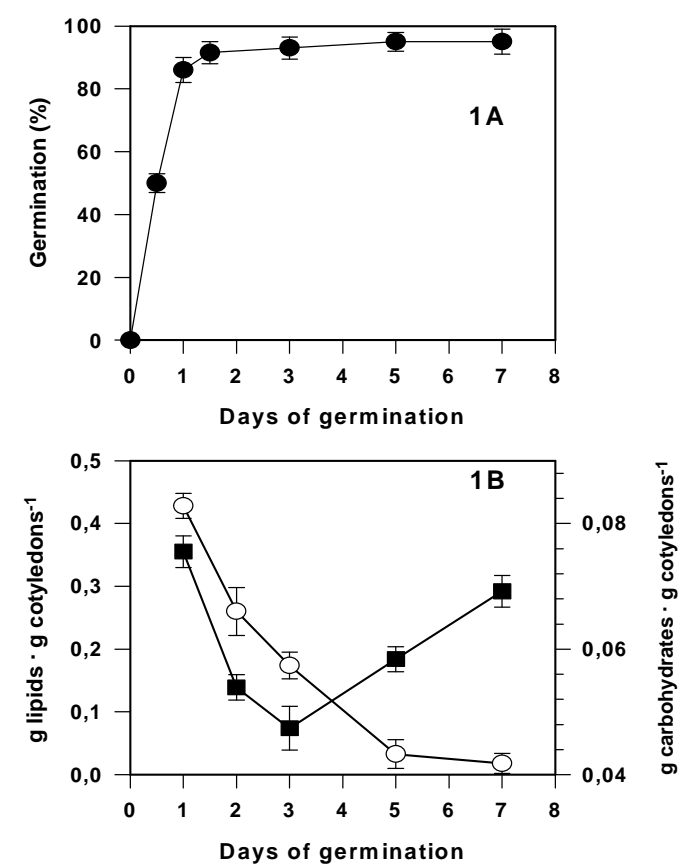

Fig. 1. Canola seed accumulated germination $(\bullet)$; total lipids $(\mathrm{O})$ and soluble carbohydrates ( ) in cotyledons

One of the aspects studied in different species is the mobilization of reserve compounds during seed germination. Non-germinated canola seed contain about $0.4 \mathrm{~g}$ lipid $\mathrm{g}$ cotyledons $^{-1}$ (Nykiforuk and JohnsonFlanagan, 1994) and $0.08 \mathrm{~g}$ of soluble carbohydrate $\mathrm{g}$ cotyledons $^{-1}$ (Naczk et al. 1997). Carbohydrates and lipids in cotyledons are metabolized during seed germination and their products are used in root and seedling growth. As the Fig. 1B shows, lipids decreased during seed germination, evidencing the use of these reserves in cotyledons. This has been 
described in other species such as Medicago sativa (Huang and Grunwald, 1990) and Citrus lemon (Garcia-Agustin et al. 1992) also. Carbohydrates had different behavior. They decreased during the first three days and reached higher values during the next four days of germination. Lipid mobilization was evident from the first day of germination and, after the third day, it coincided for a moment with the increase of carbohydrates. On fifth day of germination, all lipids had already been mobilized. Thus, we chose to work with seeds germinated after three days because, on this day they showed expressive increase in the germination percentage and significant mobilization of lipids and carbohydrates.

Caprylic acid, at different concentrations caused changes in canola seed germination when compared with control without fatty acid. This compound retarded the germination and the aspect of the roots was modified: diminishing the lengths of the roots and increasing their diameters. These effects were evident with the increase of the fatty acid concentration: $10 \mathrm{mM}$-caprylic acid inhibited seed germination completely. On the other hand, oleic acid did not influence seed germination in the concentrations studied. These results were compatible with data of Gallardo et al. (1994) which concluded that short-chain fatty acids $\left(\mathrm{C}_{6} \quad \mathrm{C}_{10}\right)$ inhibited chickpea seed germination. The germination percentage with $5 \mathrm{mM}$-caprylic acid decreased $96 \%$ when compared with control. Our results also agree with the data of Sekya et al. (1986). These authors reported that saturated fatty acids $\left(\mathrm{C}_{12}-\mathrm{C}_{18}\right)$ and oleic acid, at $4 \mathrm{mM}$ concentration had little effect on rice seed germination. In the case of oleic acid, the germination percentage was next to $93 \%$ and, therefore, similar to the control.

Fig. 2 shows soluble carbohydrates and total lipids in cotyledons after three-day germination in the presence of $1 \mathrm{mM}$ (B) and $10 \mathrm{mM}$ (C) oleic acid. Carbohydrate rates increased $21 \%$ and $33 \%$, respectively. On the other hand, lipid rates did not altered.

Fig. 3 shows soluble carbohydrate and total lipids in cotyledons after three-day germination in the presence of $1 \mathrm{mM}(\mathrm{B})$ and 5
mM (C) caprylic acid. Carbohydrate rates increased $73 \%$ and $33 \%$, respectively. Unlike oleic acid, caprylic acid increased lipid rates in cotyledons: $138 \%$ with $1 \mathrm{mM}$ (E) and $212 \%$ with $5 \mathrm{mM}(\mathrm{F})$. In this latter experimental condition, the lipid concentration verified was similar to that present in non-germinated seeds.

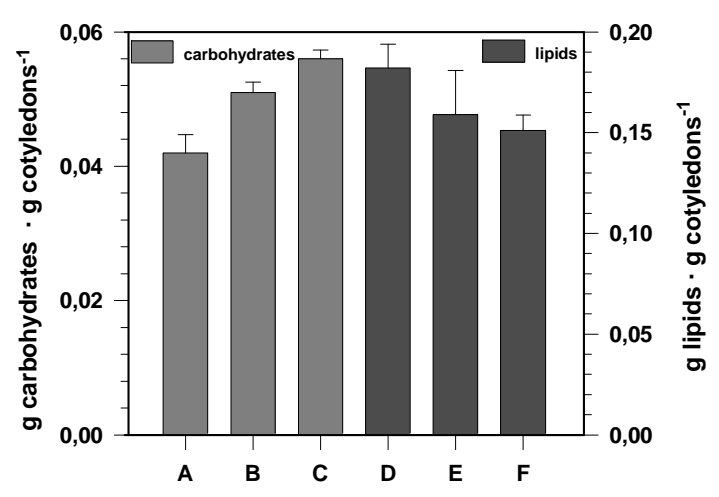

Fig. 2. Soluble carbohydrates and total lipids in canola cotyledons in the presence of the oleic acid. A: carbohydrate control; D: lipid control; $\mathbf{B}$ and $\mathbf{E}$ : 1 mM-oleic acid; C and F: 10 mM-oleic acid

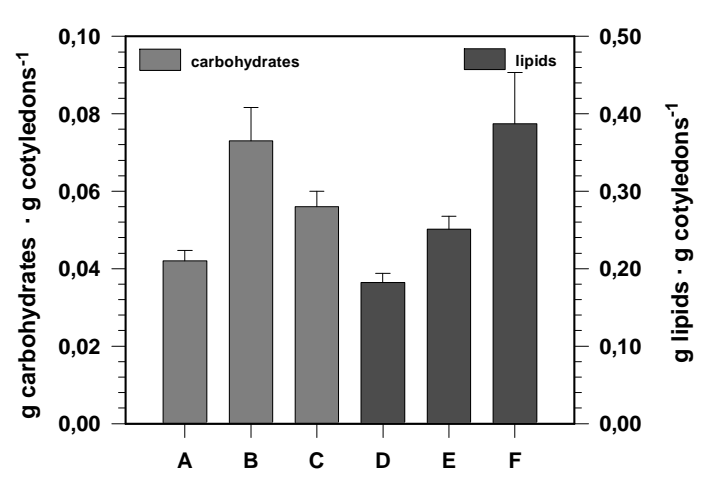

Fig. 3. Soluble carbohydrates and total lipids in canola cotyledons in the presence of the caprylic acid. A: carbohydrate control; D: lipid control; B and E: 1 mM-caprylic acid; $\mathbf{C}$ and F: $10 \mathrm{mM}-$ caprylic acid.

The results of the present investigation may be analyzed from two different points of view: the effects of fatty acids on carbohydrate metabolism and fatty acid absorption associated with low mobilization. Enzyme 
inhibition causes accumulation of carbohydrate reserves in cotyledons and may explain the increase of these molecules after three-day germination. According to this possibility, Buller et al. (1976) showed that 2-to-11-carbon fatty acids inhibited amylolysis of barley seeds. Marambe et al. (1992) reported that $\alpha$ amylase activity of sorghum seeds was the physiological process most affected by longchain fatty acids during the initial phase of germination. Vincenzini et al. (1973) reported that isocitrate lyase was inhibited by caprylic or oleic acids during Pinus pinea seed germination. This inhibition was dependent on fatty acid concentration and chain-length and it was verified that both compounds stop the de novo synthesis of the enzyme.

On the other hand, Hendricks and Taylorson (1976) reported that short-chain fatty acids could infiltrate membrane lipids and changed their physical properties, thus the physiological characteristics of the seeds would also change and as the membrane lipids lose their normal organization, the capacity for successful germination was lost. An increase of the fluidity could alter the kinetics of membraneassociated enzymes, specific permeability characteristics or any other process required for germination (Stewart and Berrie, 1979). When added to a culture medium, short-chain fatty acids seemed to affect the properties of the membrane into which they may be incorporated, increasing its fluidity (Metzer and Sebesta, 1982). They also changed the properties of the plasmalemma and other membrane systems, affecting water potential and ionic exchange of the embryonic axes (Babiano et al. 1989).

The present investigation suggests that caprylic acid has significant effects on lipids during canola seed germination but the mechanism involved is still unknown. Caprylic acid absorption by roots and its effects on lipases and isocitrate lyase in cotyledons may explain these effects.

\section{RESUMO}

O presente trabalho foi realizado com o objetivo de investigar os efeitos dos ácidos caprílico $\left(\mathrm{C}_{8}\right)$ oleico $\left(\mathrm{C}_{18}\right)$ sobre carboidratos e lipídeos durante a germinação de sementes de canola. Os resultados mostraram que ácido oleico influencia a concentração de carboidratos mas não altera a concentração de lipídeos. Resultados significativos foram encontrados com ácido caprílico que afetou tanto carboidratos como lipídeos, nos cotilédones, após três dias de germinação.

\section{REFERENCES}

Babiano, J. M.; Nicolas, G. \& Matilla, A. (1989), Changes in the cellular permeability of the embryonic axes in Cicer arietinum L. seeds during germination. Biol. Plant., 31, 92-99.

Buller, D. C.; Parker, W. \& Reid, J. S. D. (1976), Short-chain fatty acids as inhibitors of gibberellin-induced amylolysis in barley endosperm. Nature, 260, 169-170.

Dubois, M.; Gilles, K. A.; Hamilton, S. D. K.; Rebers, P. A. \& Smith, F. (1965), Colorimetric method for determination of sugar and related substances. Anal. Chem., 28, 250-256.

Gallardo, M.; De Rued, P. M.; Matilla, A. J. \& Sanches-Calle, I. M. (1994), Effect of short-chain fatty acids on the ethylene pathway in embryonic axes of Cicer arietinum during germination. Physiol. Plant., 92, 629-635.

Garcia-Agustin, P.; Benaches-Gastaldo, M. J. \& Primo-Millo, E. (1992), Lipid mobilization in Citrus cotyledons during germination. J. Plant Physiol., 140, 1-7.

Haesler, R. (1974), Influ $\beta$ von gesättigten Fettsäuren und Wachstum von hoberen. In: Pflanzen. Juris. Druck and Verlag, Zürich. Pp. 10-35.

Hendricks, S. B. \& Taylorson, R. B. (1976), Variation in germination and amino acid leakage of seeds with temperature related to membrane phase change. Plant Physiol., 58, 7-11. 
Huang, L-S \& Grunwald, C. (1990), Lipid and fatty acid changes during germination of alfalfa seeds. Phytochem., 29, 1441-1445.

Knight, J. A.; Anderson, S. \& Rawle, J. M. (1972), Chemical basis of the sulfophosphovanillin reaction for estimating total serum lipids. Clin. Chem., 18, 199202.

Marambe, B.; Nagaoka, T. \& Anso, T. (1993), Identification and biological activity of germination-inhibiting long-chain fatty acids in animal-waste composts. Plant Cell Physiol., 34, 605-612.

Metzer, J. D. \& Sebesta, D. K. (1982), Role of endogenous growth regulators in seed dormancy of Avena fatua. I. Short chain fatty acids. Plant Physiol., 70, 1480-1485.

Naczk, M.; Amarowicz, R. \& Shahidi, F. (1997), $\alpha$-Galactosides of sucrose in foods: Composition, flatulence-causing effects, and removal. In: Antinutrients and phytochemicals in food. Washington: (Ed.) F. Shahidi, American Chemical Society, New York. Pp. 127-151.

Nykiforuk, C. L. \& John-Flanagan, A. M. (1994), Germination and early seedling development under low temperature in canola. Crop Sci., 34, 1047-1054.
Sekya, J.; Kajiwara, T.; Hatanaka, A. \& Ishida, S. (1986), Inhibition of rice seed germination by long chain fatty acids. Phytochem., 25, 2733-2734.

Stevenson, F. J. (1966), Lipids in soil. J. Am. Oil. Chem., 42, 206-210.

Stewart, R. R. C. \& Berrie, A. M. M. (1979), Effect of temperature on the short-chain fatty acid-induced inhibition of lettuce seed germination. Plant Physiol., 63, 61-62.

Vincenzini, M. T.; Vincieri, F. \& Vanni, P. (1973), The effects of octanoate and oleate on isocitrate lyase activity during the germination of Pinus pinea seeds. Plant Physiol., 52, 549-553.

Wanner, H. \& Stocker, H. (1977), Different effects of long chain fatty acids on seed germination. Biochem. Physiol. Pflanzen., 171, 391-399.

Whitehead, C. S. \& Halevy, A. H. (1989), Ethylene sensitivity: the role of short-chain saturated fatty acids in pollination-induced flowers. Plant Growth Regul., 8, 41-54. 